\title{
Improve Our Understanding on the Effect of Lead Time Forecasting in Wrf Over Northern - Cameroon Region.
}

\section{Kaissassou Samuel ( $\sim$ kaisaah@yahoo.fr)}

University of Yaounde I: Universite de Yaounde I https://orcid.org/0000-0002-5905-4308

\section{Armand Komkoua}

University of Dschang: Universite de Dschang

Pascal Igri

University of Yaounde I: Universite de Yaounde I

Romeo Tanessong

University of Dschang: Universite de Dschang

\section{Guy Embolo}

University of Yaounde I: Universite de Yaounde I

\section{Achille Melingui}

University of Yaounde I: Universite de Yaounde I

Honore Rigong

University of Yaounde I: Universite de Yaounde I

\section{Research Article}

Keywords: Lead time, high-resolution forecast, extreme rainfall, North-Cameroon

Posted Date: January 25th, 2022

DOI: https://doi.org/10.21203/rs.3.rs-1239306/v1

License: (9) This work is licensed under a Creative Commons Attribution 4.0 International License. Read Full License 


\section{Abstract}

A Weather Research and Forecasting (WRF) model at a horizontal resolution of $12 \mathrm{~km}$ has been analysed for the month of July 2018 over the North region of Cameroon. For the first time, a high-resolution WRF version 3.7 is being run operationally over this part of the country for wet weather forecast. In such a study, detailed validation of the WRF model is crucial. Therefore, the validation of mean parameters including wind distribution, relative humidity and rainfall, over the entire region within all the forecast lead time, is essential. Validation is done by comparing WRF outputs to ERA5, ARC2 and observed upper air data. It is found that the model captures accurately relative humidity and low level wind events with sufficiently shorter lead times (3 days), while the same performance is observed for extreme precipitable water and rainfall but at longer lead time as well as the diurnal variability of these parameters associated with wet season at all lead times. Furthermore, the accuracy of WRF in predicting spatiotemporal changes of some atmospheric variables decreases with increase in lead time.

\section{Introduction}

The northern regions of Cameroon are recurrently affected by floods which cause lot of damages (Igri et al. 2018). Particularly, the Far North region of the country in recent years has suffered from extreme events, which push the populations to relocate in unsuitable habitat. These displaced people faced several health problems, especially the spread of epidemics as water-borne diseases reported by United Nation Office for the Coordination of Humanitarian Affairs (UNOCHA), 2021. Among these disasters, the most grievous one was recorded in Logone-and-Chari and Mayo-Danay Divisions on 22-23 July 2018 (Igri et al. 2015). The economic losses were estimated at several million dollars and 12 people were killed. During the wet season (June-July-August-September), the westerly winds originated from the Atlantic Ocean dominated the region (Kaissassou et al. 2015a-b) as the monsoon flow is well established at this period. The Harmattan wind is pushed northward above $12^{\circ} \mathrm{N}$. North-Cameroon has over 8 million inhabitants. This Region undergoes very hot and dry climate for almost 8 months within which rain scarcity is observed (Issa et al. 2010). The month of May is proved to be the real beginning of the monsoon period corresponding to the rainy season which ends in October.

The WRF model was implemented to serve as a tool in weather forecasting and specifically for the forecasting of dangerous events. In numerical model, especially in Africa, precipitation is considered as one of the most significant outputs (Kaissassou et al. 2020; Tanessong et al. 2017). So, most modelling researchers focus their efforts on understanding and improving on their knowledge in rain variability at various space time scales. Rainfall, wind and humidity have been chosen for the purpose as they are among the most important parameters affecting socio-economic activities in this region.

In the past few years, researchers explored the meteorological conditions that favour the occurrence of extreme floods and at which time they happen over the world (Kim et al. 2018; Joseph et al. 2018). Investigations were undertaken with Weather Research and Forecasting (WRF) model to capture convection and extreme rainfall worldwide. For instance, in India, Sinh et al. (2008) analysed the extreme 
rainfall with Mesoscale Model. In the same view, Kumar et al. (2008) simulated convection and heavy rain with WRF. Some studies, aimed at monitoring heavy rainfall events through mesoscale models, have been done. Indeed, Vondou et al. (2021) analysed trends and interannual variability of extreme rainfall indices over Cameroon. Mugume et al. (2017) tested the fidelity of the WRF model to capture rainfall over Western Uganda.

In spite of some weather forecasts provided, for the whole Cameroonian territory, by the Direction of National Meteorology (DNM), the demand is still stronger as regards the quality forecast in due time over the country. This demand is particularly high in the study area in which extreme events become more and more recurrent. Thus, the investigation of floods outbreak due to extreme rainfall (Nandargi et al. 2015; Xiangrui et al. 2019) over most northern Cameroon cities is the first concern of this paper. Seeking requirement for quality and useful forecast over these regions would enhance and improve on weather service supply and afterwards allow extending the study to the whole country.

The present study is performed by using the WRF model, aiming to provide an understanding of the effect of lead time in forecasting over the Northern Cameroon, improve on predictability of extreme events and suggest how future disasters in this part of the country might be better anticipated, as demands increase at Direction of Civil Protection (DCP). One particular peak spell of heavy rainfall that occurred on 22-23 July 2018 over the northern regions of Cameroon is considered for the current research work. The paper is structured as follows: Synoptic conditions during 22-23 July 2018 is described in Section. 2. NWP model details are provided in Section. 3. Section 4 is about the data sources. The model results are compared to observations in Section. 5. Then conclusions are drawn in the final section.

\section{Synoptic Conditions During 22 - 23 July 2018}

During the July-August-September (JAS) season in 2018, the northern regions of Cameroon (Hatched area in Fig. 1) underwent several rainfall episodes with the highest impact recorded on $22-23$ July.

Figure 2 shows the daily total rainfall recorded at Ngaoundere weather station on 22, 23 and 24 July 2018. The amount of rainfall recorded during 22-23 July, was higher than $85 \mathrm{~mm}$. The prominent feature depicted in Fig. 2 is the occurrence of a maximum noticed on July 23 with accumulated rainfall around $60 \mathrm{~mm}$. Figures 3 illustrates the radiosoundings performed at Ngaoundere airport's weather station on 18, 19, 20 and 23 July 2018. The instability of the atmosphere which favours cloud formation and development is usually detected by radiosounding. These figures present different parameters: PIcl and TIcl represent the pressure and the temperature values at the lifting condensation level respectively. Plcl indicates that the cloud base was near the surface at $900 \mathrm{hPa}(890 \mathrm{hPa})$ for the radiosounding of day-3 day- 4 (day-5). The temperature at $900 \mathrm{hPa}$ was around $23^{\circ} \mathrm{C}$ for these different days but values dropped to $21{ }^{\circ} \mathrm{C}$ on July 23. Showater index (Shox) is an important input to forecast clouds taking into account different parameters involved in the formation of storms. When the value for soundings is zero, that indicates probable presence of thunderstorms during this moment. The amount of precipitable water (Pwat) is the Vertical Integral of Water Vapour. For all the radiosoundings, the Pwat is worth about 57 
$\mathrm{mm}$. This value indicates the occurrence of intense storms. CAPE denotes the Convective Available Potential Energy. The CAPE is a convection index related to the theory of buoyancy of an air parcel. Convective Available Potential energy measures conditional convective instability and storms strength (Embolo et al. 2015; Abhik et al. 2017). There was a persistent instability in the northern regions of Cameroon during this period as demonstrated clearly by the values obtained for both soundings. The value of CAPE reaches $1643 \mathrm{~J} / \mathrm{kg}$ on July 22, 2018 at 1200 UTC implying severe unstable atmosphere conditions which might lead to severe storm. On July 23 at 0000 UTC, the CAPE is $814 \mathrm{~J} / \mathrm{kg}$, which is associated to almost stable conditions.

\section{Data Sources Station data}

Climatology data of North regions of Cameroon were collected from observations of Vaisala RS-80 sondes located at Ngaoundere $\left(13.5^{\circ} \mathrm{E}, 7.3^{\circ} \mathrm{N}\right.$ and $1104 \mathrm{~m}$ above sea level airport (Fig.1), which provided every $10 \mathrm{~s}$ a high vertical resolution (about $5 \mathrm{~m}$ height). These Data are also used since 1961 by the National Meteorological Service (MNS) of Cameroon.

\section{ARC2 data}

The new, operational African Rainfall Climatology Version 2 (ARC2) dataset consists of daily, gridded $0.1^{\circ}$ $X 0.1^{\circ}$ rainfall estimates with a spatial domain from $40^{\circ} \mathrm{S}$ to $40^{\circ} \mathrm{N}$ in latitude, and $20^{\circ} \mathrm{W}$ to $55^{\circ} \mathrm{E}$ in longitude encompassing the African continent (Nicholas et al. 2013) from 1 January, 1983 to present and forward into the future.

\section{ERA 5 data}

ERA5 is a reanalysis dataset available with a global horizontal coverage, and recording in real-time. ERA5 can be downloaded from the ECMWF database with full horizontal resolution of $0.25^{\circ} \times 0.25^{\circ}$ (atmosphere) and $0.5^{\circ} \times 0.5^{\circ}$ (ocean waves)(Kaissassou et al. 2021). Temporal coverage since 1979 to present, hourly resolution and are updated daily.

\section{Nwp Model Details}

In the past few years, significant progress has been made in terms of the improvement of numerical weather prediction models. It is proven that the enhancement of the model resolution increases the model quality.

In order to fulfil the lack of information in the field of forecast in Northern Cameroon, a very highresolution version 3.7 of advanced research WRF (ARW) dynamical core for simulations with the National 
Centers for Environmental Prediction NCEP-GFS (spectral resolution about $12 \mathrm{~km}$ ) with 64 vertical levels and sea surface temperature (SST) with $1^{\circ}$ horizontal resolution have been implemented as boundary and initial conditions for operational forecast in the model.

The WRF model is run for 9 days and the output data is recorded every 3 hours. This work analyses simultaneously diurnal and daily simulate data from July, 14 to July, 23, 2018. WRF is being run at the Laboratory for Environmental Modelling of Atmospheric Physics (LEMAP) at the University of Yaoundé 1.

To validate the model forecast, the radiosoundings and very high resolution rainfall data ARC2 have been used in the present work within the same period for this purpose. These data combined in-situ measures and latest high quality research one provided by satellite (Mahakur et al. 2013). A detailed description of these data is provided in the next section.

In addition to radiosoundings and satellite data, re-analyses data have also been used to evaluate accurately the performance of the model. Thus, ERA5 wind and relative humidity database is used to further monitoring model forecast for the month of July 2018.

The diurnal and daily rainfall temporal series is calculated by adding 3 hourly data. The WRF model is initiated on 14, 18, 19, 20 and 22 July 2018 at 0000UTC, for day-9, day-5, day-3 and day-1 forecast lead times respectively. The spatial distribution of each parameter could be seen in different figures. The diurnal cycle of different parameters is computed for a 3-hour time series for the model output and also for the observation.

To improve the synoptic circulations, mesoscale features, and to capture heavy rainfall over Northern regions of Cameroon (Fig. 1), domain grids with a horizontal grid spacing of $12 \mathrm{~km}$ was provided.

\section{Results}

\subsection{Precipitable water}

Figures 4-7 show the precipitable water provided by the WRF model output, and that provided by ERA5 data at 0000 UTC, 0600 UTC, 1200 UTC and 1800 UTC for different lead times in July 2018. The precipitable water is a crucial indicator in meteorology as it gives valuable information on areas of potential instability in the troposphere particularly when its value exceeds $60 \mathrm{~mm}$. these high values are also a good input to predict flooding hazards. Around Lake Chad basin, high precipitable water values are observed. Both simulated and ERA5 precipitable water amount exceed $55 \mathrm{~mm}$ in this area. High values indicate a large quantity of tropospheric water vapour as observed in the troposphere of the northern regions of Cameroon on July 23 and 24, 2018. As depicted on Figures 4-7, WRF model simulates and predicts precipitable water successfully in north regions of Cameroon on July 23 and 242018 compared to observations. 
The water vapour supply is a crucial parameter in extreme rainfall occurrence. At 0000 UTC on July 22th, water vapour extended from South to North of Cameroon, due to monsoon flow, and lead to convergence of moist air over northern regions as indicate in Figs. 4-7. Notably, the vertical movement created favourable conditions for extreme rainfall event.

\subsection{Wind speed and Relative humidity}

In Figures 8-11 we noticed WRF simulated data (for domain $12 \mathrm{~km}$ ), ERA5 data, wind velocity $(\mathrm{m} / \mathrm{s})$, relative humidity (\% shaded) at 0000 UTC, 0600 UTC, 1200 UTC and 1800 UTC for all the lead times at the surface and $850 \mathrm{hPa}$, respectively.

At 0000 UTC, the relative humidity was up to $80 \%$ throughout Lake Chad basin; the prevailing wind blowing from South to North regions of Cameroon. This wind, charged with water vapour, supplies moisture to the region under our study. The surface wind magnitude was around $8 \mathrm{~m} / \mathrm{s}$. At 0600 UTC, 1200 UTC and 1800 UTC, the conditions were similar except from a slight decrease of relative humidity. It shows that low level air was saturated in the Northern regions of Cameroon owing to the presence of enough water vapour in the atmosphere.

At $850 \mathrm{hPa}$ pressure level, the relative humidity remained higher in the study area for both simulated data and ERA5 reanalyses (Mukhopadhyay et al. 2019). Westerly winds dominate the North region of Cameroon at $850 \mathrm{hPa}$, blowing from the South to the North of the region. This observation indicates that at this pressure level, the wind was charged with moisture.

The high values of relative humidity simulated and derived from ERA5 data, at low level on July 22th 2018 indicate that cloud formation process is taking place at ground level. The North region of Cameroon is subject to particular climate with permanent cloud occurrence during rainy season. Cumulonimbus which is source of extreme weather conditions is also present among them. We notice that the WRF model well simulates relative humidity and wind in the North of Cameroon than ERA5.

\subsection{Soundings}

Figure 12 displays the soundings generated by the 12 km WRF output for the lead times day-5, day-4, day3 and day- 1 of July 2018 in the North region of Cameroon. Soundings parameters provide key indications of atmospheric instability (Yaru et al. 2020).

Skew-P/Log-p shows dew point and temperature. The temperature of air parcel during its motion from the ground is indicated in dashed red curves. In soundings, the temperature curve follows the pseudo saturated wet adiabatic. It indicates that the air has been saturated in North regions of Cameroon on July 23,2018 . During the motion of air from ground to $750 \mathrm{hPa}$ level, air temperature and dew point temperature are very close showing cooling which can lead to condensation and formation of clouds in the northern regions of Cameroon on this day. The simulated values of pressure at the lifting condensation level (Plcl) are 957, 991, $960 \mathrm{hPa}$ on day-1, day-3 and day-5 respectively. Compare to in situ values on those days which are $974 \mathrm{hPa}$ on day-0 (23 July 2018), $1000 \mathrm{hPa}$ on day-1 and $977 \mathrm{hPa}$ on 
day-3 of July 2018, the simulated values are well correlated (Table1 and Table 2 ). The observed values of temperature at the lifting condensation point level $(\mathrm{TICl})$ are analogous to the simulated one. Figures 3 and 12 display temperature values from model simulation and observed values. That is $23^{\circ} \mathrm{C}$ on day- 1 (observed value $24^{\circ} \mathrm{C}$ ), $23^{\circ} \mathrm{C}$ on day -3 (observed value $24^{\circ} \mathrm{C}$ ) and $22^{\circ} \mathrm{C}$ day -5 (observed value $23^{\circ} \mathrm{C}$ ). The Showater indices from model output have almost same values as in situ measurements except on day-0 (23July 2018) where the model value is 0 for the observed. Furthermore, precipitable water model's values are very close to the observed one. CAPE values generated by the model (1643 J, $1395 \mathrm{~J}$ and $912 \mathrm{~J}$ ) are higher compared to the observed values $(1243 \mathrm{~J}, 812 \mathrm{~J}$ and $162 \mathrm{~J}$ respectively). Except from the CAPE which is not well correlated, others parameters like TIcl, PIcl, Shox, precipitable water are well simulated. WRF model is able to provide key information which could help stakeholders to sensitize people about extreme events like flooding recorded in North regions of Cameroon on 22-23 July 2018.

Table 1

Parameters value derived from Soundings launching at different lead times

\begin{tabular}{|lllll|}
\hline Parameters & Day - 0 & Day - 3 & Day - 5 & Day - 7 \\
\hline Plcl $(\mathrm{hPa})$ & 974 & 1000 & 977 & 952 \\
\hline Tlcl $\left({ }^{0} \mathrm{C}\right)$ & 18 & 19 & 18 & 20 \\
\hline Shox & 0 & 0 & 0 & 4 \\
\hline Pwat $(\mathrm{cm})$ & 5 & 5 & 5 & 5 \\
\hline Cape $(\mathrm{J} / \mathrm{kg})$ & 162 & 1243 & 712 & 36 \\
\hline
\end{tabular}

Table 2

Parameters value derived from WRF simulation at different lead times

\begin{tabular}{|lllll|}
\hline Parameters & Day - 1 & Day - 3 & Day - 5 & Day - 7 \\
\hline Plcl $(\mathrm{hPa})$ & 957 & 991 & 960 & 942 \\
\hline TIcl $\left({ }^{0} \mathrm{C}\right)$ & 15 & 17 & 15 & 19 \\
\hline Shox & 0 & 0 & 0 & 3 \\
\hline Pwat $(\mathrm{cm})$ & 6 & 5 & 3 & 6 \\
\hline Cape $(\mathrm{J} / \mathrm{kg})$ & 1643 & 1359 & 912 & 874 \\
\hline
\end{tabular}

\subsection{Rainfall}

The current section carried out the model simulation for different lead times amount extreme rainfall for the studied period started at lead-9 to lead-0 for the month of July 2018 for the $12 \mathrm{~km}$ domain (Fig. 13). ARC2 data are compared with these simulated one. Figures 8 and 11 present for different leads amount 
rainfall simulated by WRF model and ERA5. For extreme rainfall at longer lead time (leads 9 and 7) as shown in figure 13 , model is able to predict accurately and accuracy increases with increase in lead time. We notice also a huge turbulence area on entire Lake Chad Basin for the considering period. The great amount of precipitation could be seen as a result of a strong convective activity which prevail over this region cause by the presence of monsoon during this period. In north-Cameroon, the lower tropospheric layers receive an important quantity of energy by evaporation and sensible heat flux. This leads air to rapidly reach the lifting condensation level. The condensation process starts with a moist convection which transfer latent energy of ground level layer to upper layers in term of potential energy. When the monsoon reaches it most dominant period, as seen in forecasts, severe storms conditions may occur.

\section{Conclusion}

The Northern areas of Cameroon suffered from an unusual extreme rainfall event during 22-23 July 2018. The amount of rainfall recorded for the two days, exceeded $90 \mathrm{~mm} /$ day and caused flash floods, loss of life and several others damages in this region. In this study, model's ability to predict extreme rainfall, relative humidity, precipitable water and wind in North - Cameroon region is investigated. Using WRF model over this domain with horizontal resolutions of $12 \mathrm{~km}$, outputs data produced are compared to ERA5 and ARC2 data. As for precipitable water, relative humidity, low level wind ( $850 \mathrm{hPa}$ ).

Radiosoundings from Ngaoundere airport indicate that this extreme was combined with the downfalls, thunderstorms and high values of Vertical Integral of relative humidity indicating the presence of intense pouring rain. Convective Available Potential Energy values obtained by computing radiosoundings plainly show that there was a ceaseless instability in Northern regions of Cameroon on the target day at all the lead times. This episode is well simulated by WRF model, bounded and initialized for Environmental Prediction Global Forecasting System $3 \mathrm{~h}$ products. It is found that model is able to predict extreme relative humidity and low level wind events accurately with sufficiently short lead time (3 days). For extreme precipitable water and rainfall at longer lead time, model is able to predict accurately and accuracy increases with increase in lead time. The WRF got the ability to generate crucial meteorological variables associated with this extreme, as successful simulation of the Vertical Integral of Water Vapour with the magnitude like that produced from radiosoundings (Chien and Chiu, 2021). Furthermore, simulate data forecast and observations are more correlated when the forecast is released on the target day. Thus, Forecasters might pay attention to lead time effect when analysing WRF model outputs in order to have a successful prediction of extreme events. Although WRF has a reasonable skills in predicting the spatiotemporal parameters of the atmosphere, further improvement is necessary to enhance the fidelity of capture severe rainfall episode with a larger lead time.

\section{Declarations}

\section{Funding:}




\section{Institutional Review Board Statement:}

Not applicable.

\section{Informed Consent Statement:}

Not applicable.

\section{Data Availability Statement:}

The data used in this study are available on request from the corresponding author. Due to the large amount of the data, they are not publicly available.

\section{Acknowledgments:}

The authors are very grateful to ASECNA Ngaoundere for making available the radiosonde data of the Ngaoundere airport used for the analysis and DMN service of Garoua town. ERA5 data were obtained from the ECMWF website.

\section{Conflicts of Interest:}

The authors declare no conflicts of interest.

\section{Author Contributions}

Samuel Kaissassou developed code, designed, performed and analysed the simulation experiments and prepared the manuscript with contributions from all co-authors. P. Igri, A. Komkoua, A. Melingui, and G. Embolo supervised the research, co-designed the experiments and reviewed the manuscript. H. Rigong, and R. Tanessong performed figures and quality control of data.

\section{References}

1. Abhik S, Krishna RP, Mahakur M, Ganai M, Mukhopadhyay P, Dudhia J (2017) Revised cloud processes to improve the mean and intraseasonal variability of Indian summer monsoon in climate forecast system: Part 1; J. Adv. Model. Earth Syst. 9(2) 1002-1029. 
2. Chien, FC, Chiu YC (2021) Assessing the Impact of Dropsonde Data on Rain Forecasts in Taiwan with Observing System Simulation Experiments..Atmosphere 12, 1672. tps://doi.org/10.3390/ atmos12121672.

3. Embolo G, Lenouo A, Nzeukou A, Vondou DA, Mkankam K (2015) On convection and static stability during the AMMA SOP£ campaign. Theoretical and applied Climatology 127(1):197-211. Doi: 10.1007/s00704-015-1627-3

4. Igri PM, Tanessong R, Vondou DA, Jagabandhu P, Adamou G, Mkamkan K, Kamga A (2018) Assessing the performance of WRF model in predicting high-impact weather conditions over Central and Western Africa: an ensemble-based approach. Nat Hazards (2018) 93:1565-1587

5. Igri PM, Tanessong RS, Vondou DA, Mkankam FK, Panda J (2015) Added-value of 3DVAR data assimilation in the simulation of heavy rainfall events over western and central Africa. Pure Appl Geophys 172:2751-2776

6. Issa L, Lamb M, Peter J (2010) Variability of the intertropical front (ITF) and rainfall over the West African Sudan-Sahel zone. J Clim 23:3984-4004

7. Joseph S, Mandal R, Sahai AK, Phani R, Dey A, Chattopadhyay R (2018) Diagnostics and real-time extended range prediction of heat waves over India; IITM Research Report (ISSN 0252-1075), ESSO/ IITM/SERP/SR/03(2018)/192.

8. Kaissassou S, Djiotang L, Komkoua A, Ekobo B, Ndzana B, Tanessong R, Guenang M, Vondou DA (2021) Climatology of super-refraction and trapping layers conditions over Central and West Africa Meteorol Appl. 2021;28:e2016. https://doi.org/10.1002/met.2016

9. Kaissassou S, Lenouo A, Nzeukou A, Tchawoua C, Vondou DA (2015a) Seasonal variations of surface duct conditions in Ngaoundere, North Cameroon. Meteorology and Atmospheric Physics, 127, 659-674. https://doi.org/10.1007/s00703-015-0387-z

10. Kaissassou S, Lenouo A, Tanessong RS, Tamo K, Vondou A, Pokam W (2020) Investigation of anomalous propagation conditions in Central and West Africa stations using high-resolution GPS radiosonde observations. Journal of Earth System Science, 129, 220.

https://doi.org/10.1007/s12040-020-01477-y

11. Kaissassou S, Lenouo A, Tchawoua C, Lopez P, Amadou T (2015b) Climatology of anomalous propagation radar over West Africa. Journal ofAtmosphericandSolar-Terrestrial Physics, 123, 1-12.

12. Kim IW, Oh J, Woo S, Kripalani RH ( 2018) Evaluation of precipitation extremes over the Asian domain: Observation and modelling studies; Clim. Dyn. https://doi.org/10.1007/s00382-018-4193-4.

13. Kumar A, Dudhia J, Rotunno RM, Niyogi D, Mohanty U (2008) Analysis of the 26 July 2005 heavy rain event over Mumbai, India using the Weather Research and Forecasting (WRF) model. Q J R Meteorol Soc 134:1897-1910.

14. Mahakur M, Prabhu A, Sharma AK, Rao VR, Senroy S, Singh R, Goswami B (2013) High-resolution outgoing longwave radiation dataset from Kalpana-1 satellite during 2004-2012; Curr.

Sci. 105 1124-1133. 
15. Mugume I, Waiswa D, Mesquita MDS, Reuder J, Basalirwa C, Bamutaze Y, Twinomuhangi R, Tumwine F, Sansa Otim J, Jacob Ngailo T, Ayesiga G (2017) Assessing the performance of WRF model in simulating rainfall over western Uganda. J Climatol Weather Forecast 5(1):197

16. Mukhopadhyay P, Prasad VS, Phani Murali Krishna, Medha Deshpande, Malay Ganai, Snehlata

17. Nandargi S, Gaur A 2015 Extreme rainfall events over the Uttarakhand State (1901-2013); Int. J. Sci. Res. 4(4)700-703.

18. Nicholas SN, Thiaw W (2013) African Rainfall Climatology Version 2 for Famine Early Warning Systems Journal of applied meteorology and climatology V. 52 p.588-606 DOI: 10.1175/JAMC-D-110238.1 .

19. Singh R, Pal PK, Kishtawal CM, Joshi P (2008) Impact of atmospheric infrared sounder data on the numerical simulation of a historical Mumbai rain event. Weather Forecast 23:891-913

20. Tanessong S, Vondou DA, Yepdo Djomou Z, Moudi Igri P (2017) WRF high resolution simulation of an extreme rainfall event over Douala (Cameroon): a case study Model. Earth Syst. Environ. 3:927942 DOI 10.1007/s40808-017-0343-7

21. Vondou DA, Guenang M, Djiotang L, Kamsu-Tamo H (2021) Trends and Interannual Variability of Extreme Rainfall Indices over Cameroon. Sustainability 2021, 13, 6803. https://doi.org/10.3390/ su13126803

22. Xiangrui L, Fan K, Yu Entao Y (2019) Hindcast of extreme rainfall with high-resolution WRF: model ability and effect of physical schemes. Theoretical and Applied Climatology https://doi.org/10.1007/s00704-019-02945-2

23. Yaru Dai, Weilin Pan, Xiong Hu, Zhixuan Bai, Chao Ban, Hengheng Zhang, Yunfei Che (2020) An approach for improving the NRLMSISE-00 model using a radiosonde at Golmud of the Tibetan Plateau. Meteorology and Atmospheric Physics 132:451-459 https://doi.org/10.1007/s00703-01900700-w

\section{Figures}




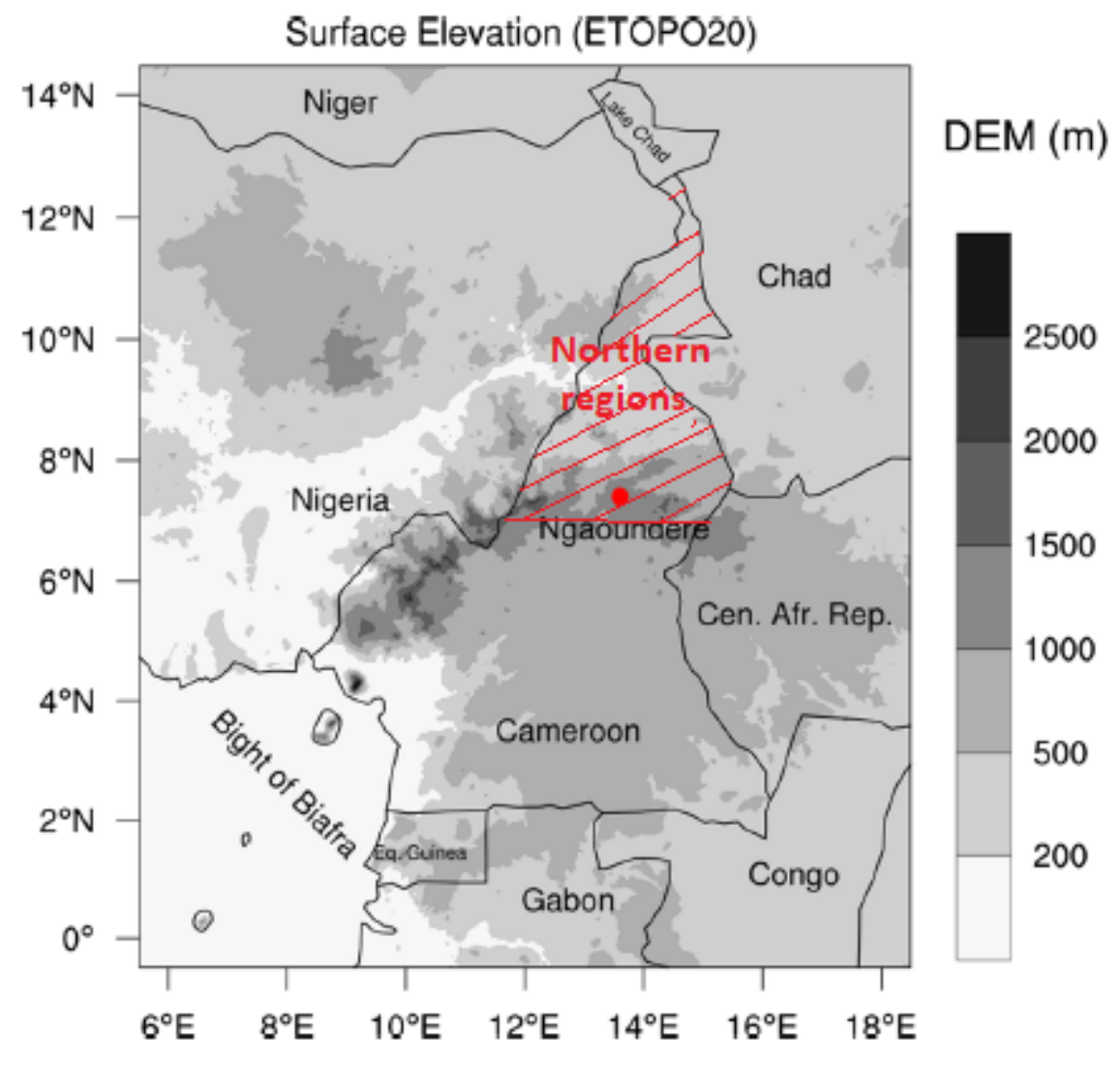

Figure 1

Map of Cameroon and its northern regions. 


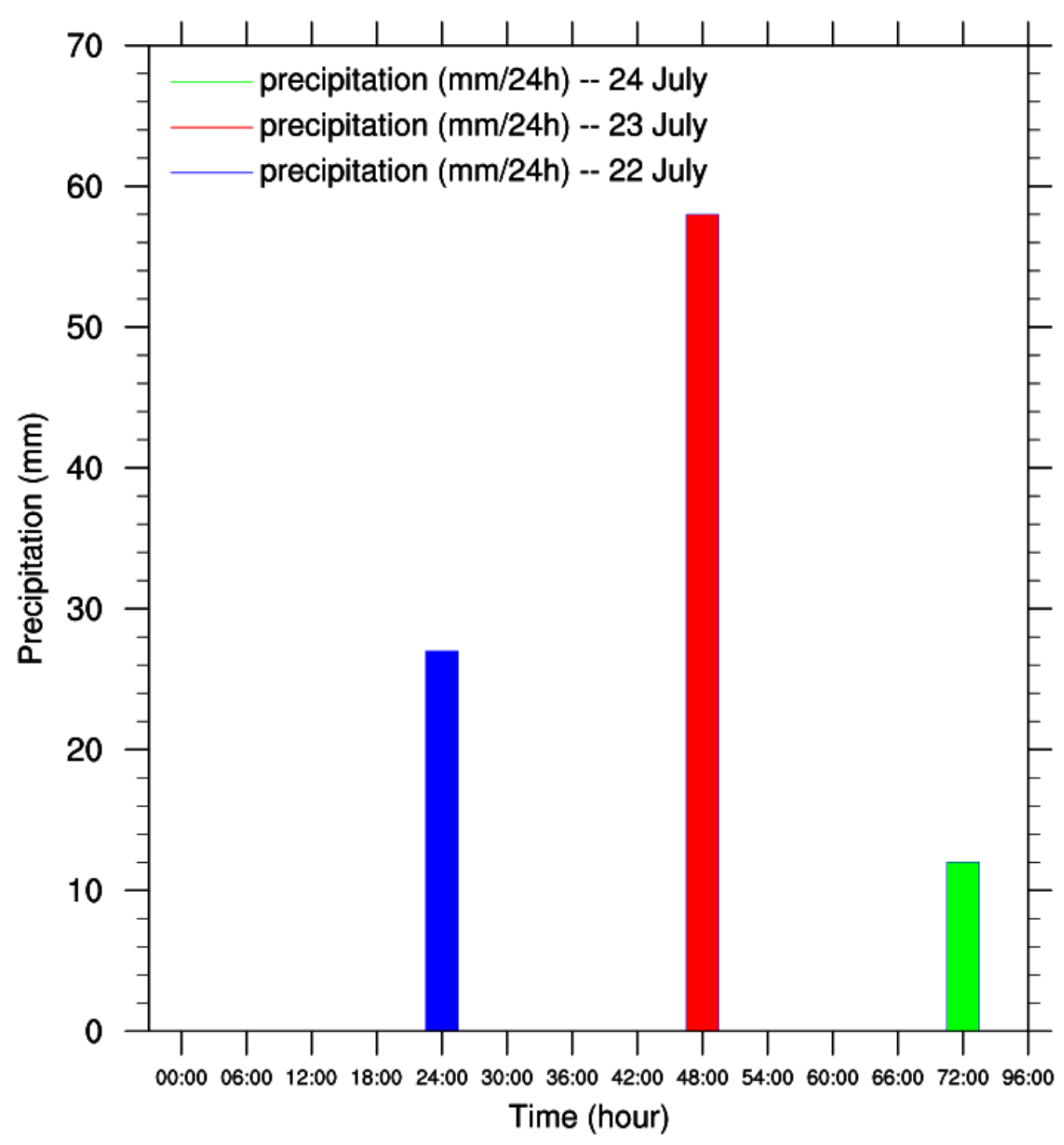

Figure 2

The temporal distribution of daily rainfall starting from 0000 UTC 22 July 2018 . The x-axis represents the hours after 0000 UTC 22 July. 

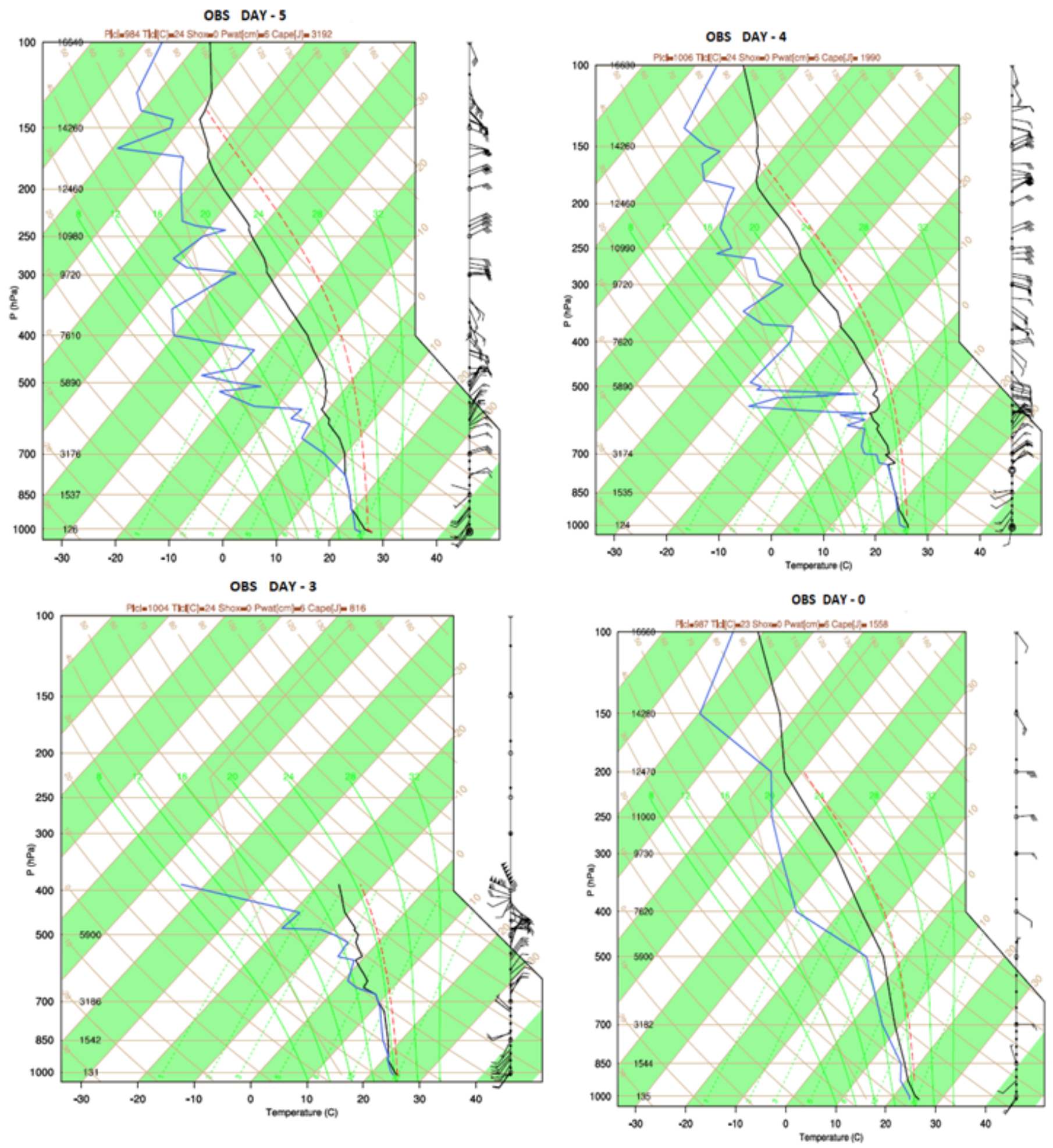

\section{Figure 3}

Radiosoundings from the Ngaoundere Airport on day-5, day-4, day-3 and 23 July $2018 \mathrm{Plcl}$ and T/C/ the pressure $(\mathrm{hPa})$ and the temperature $\left({ }^{\circ} \mathrm{C}\right)$ at the lifting condensation level, Shox Showater index, $P$ wat the amount of precipitable water, Cape the convective available potential energy $(\mathrm{J})$ 

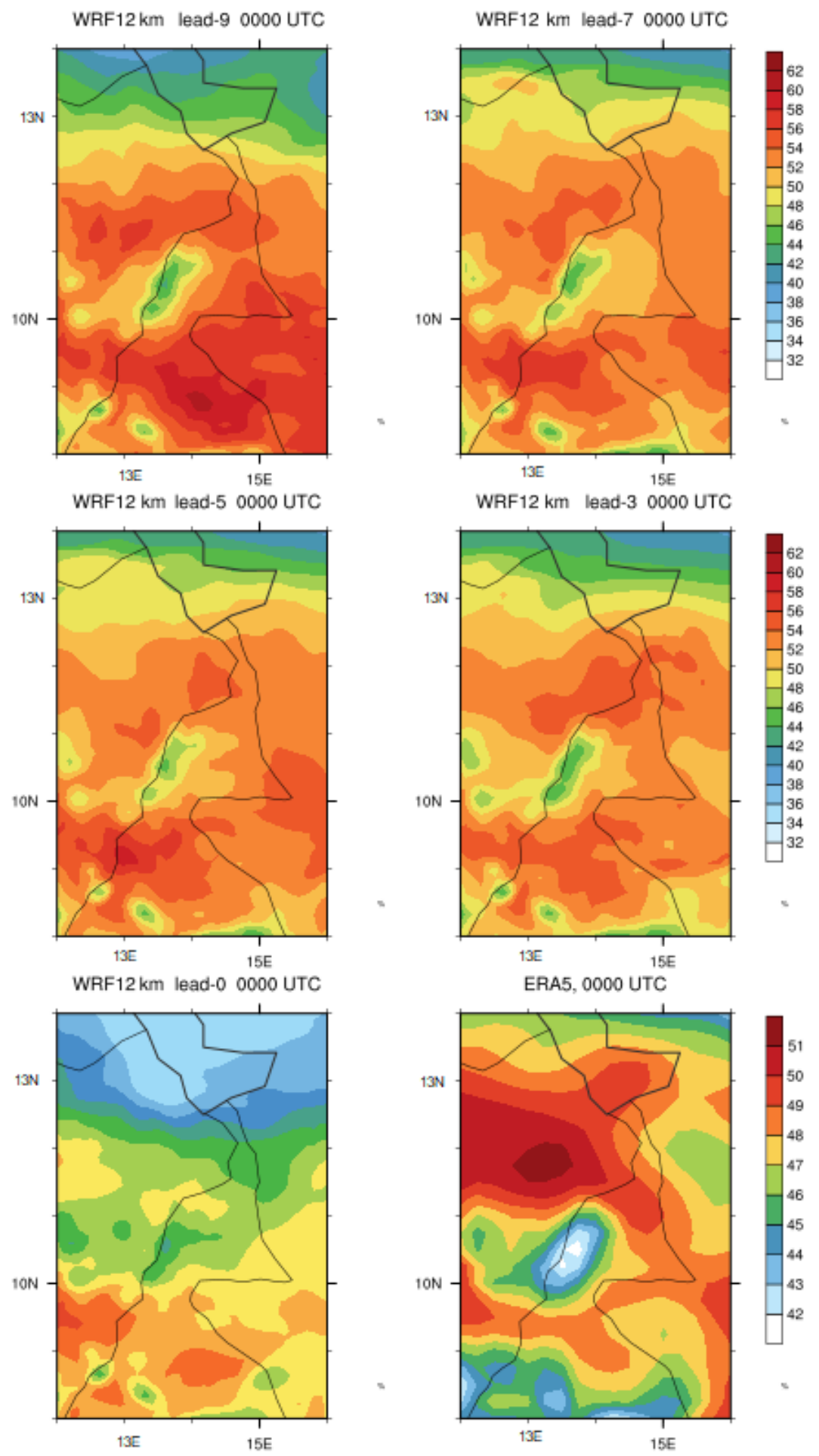

Figure 4

Comparison of WRF simulated precipitable water with ERA5 precipitable water at 0000 UTC for lead time $9,7,5,3$ and 0 . 

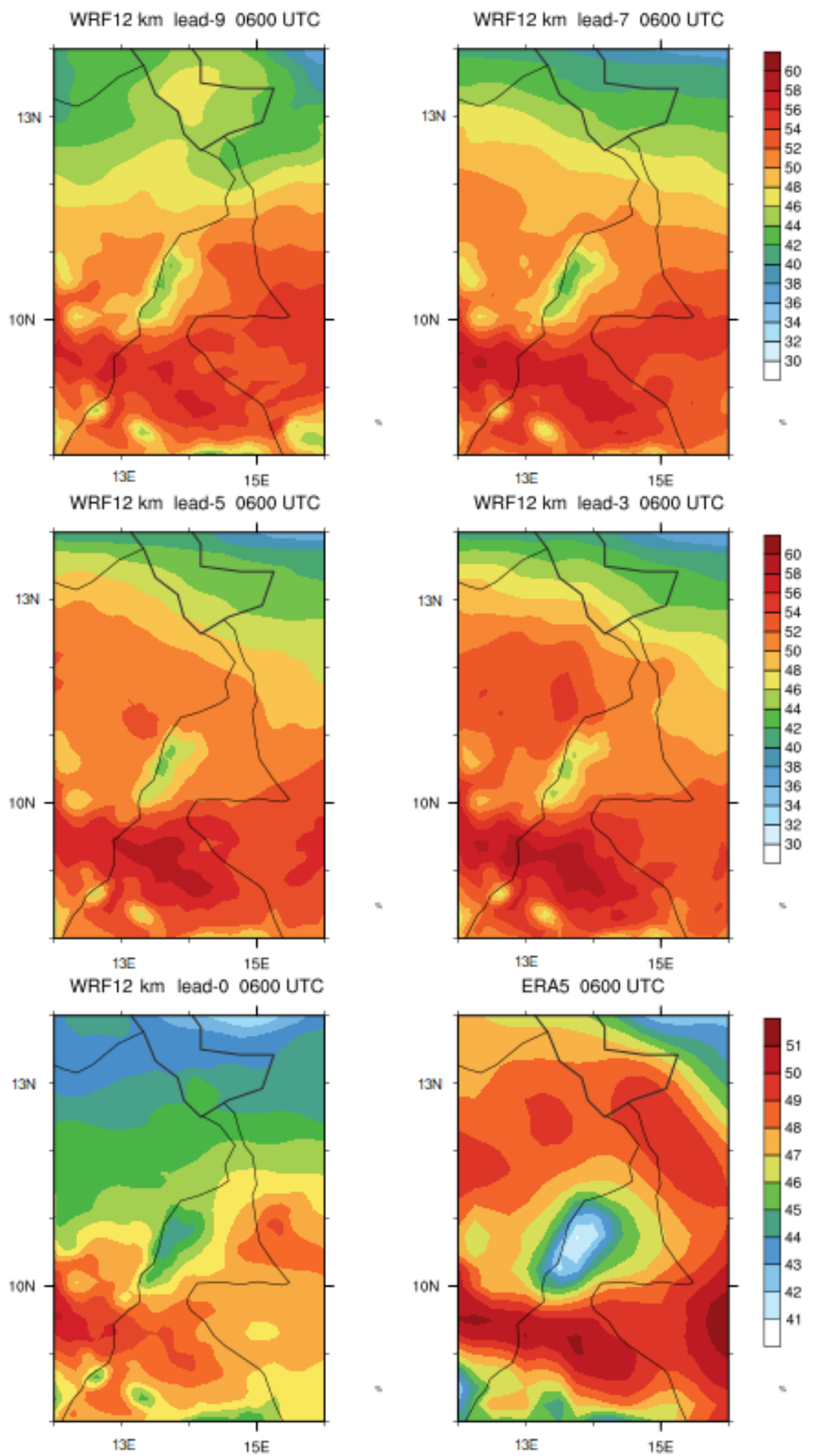

Figure 5

Same as Fig. 4, but at 0600 UTC. 

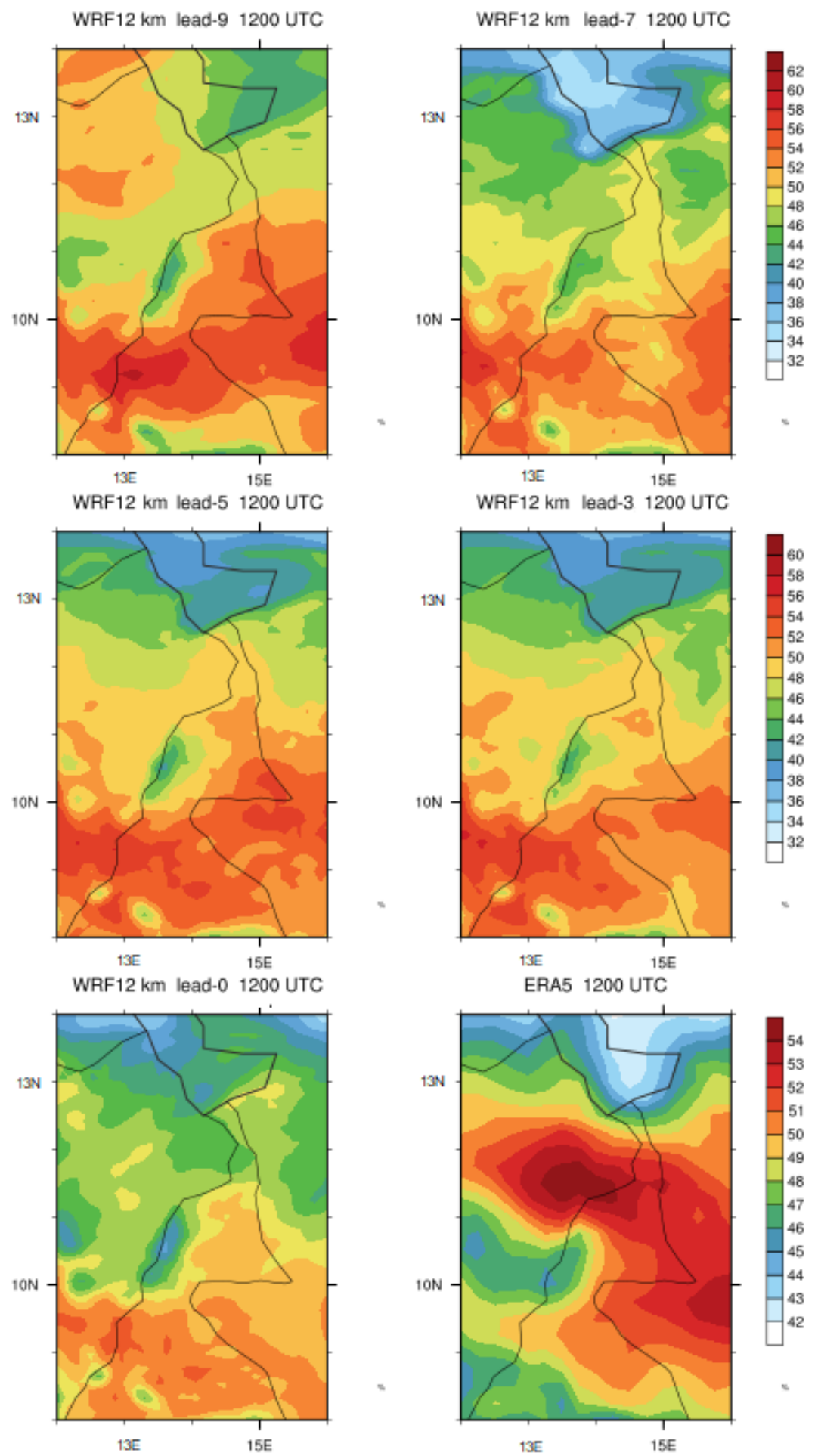

Figure 6

Same as Fig.4, but at 1200 UTC. 

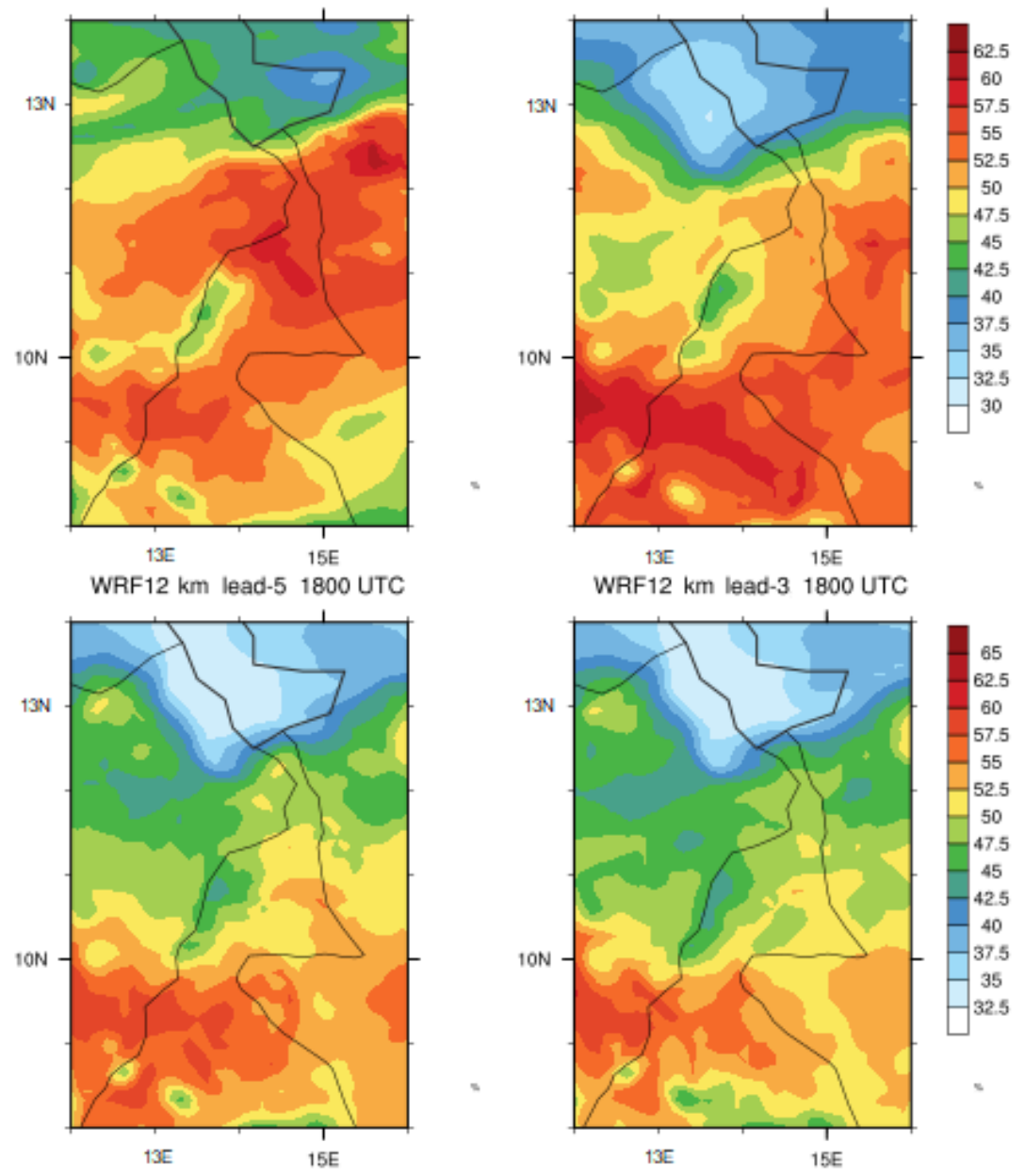

WRF12 km lead-3 1800 UTC
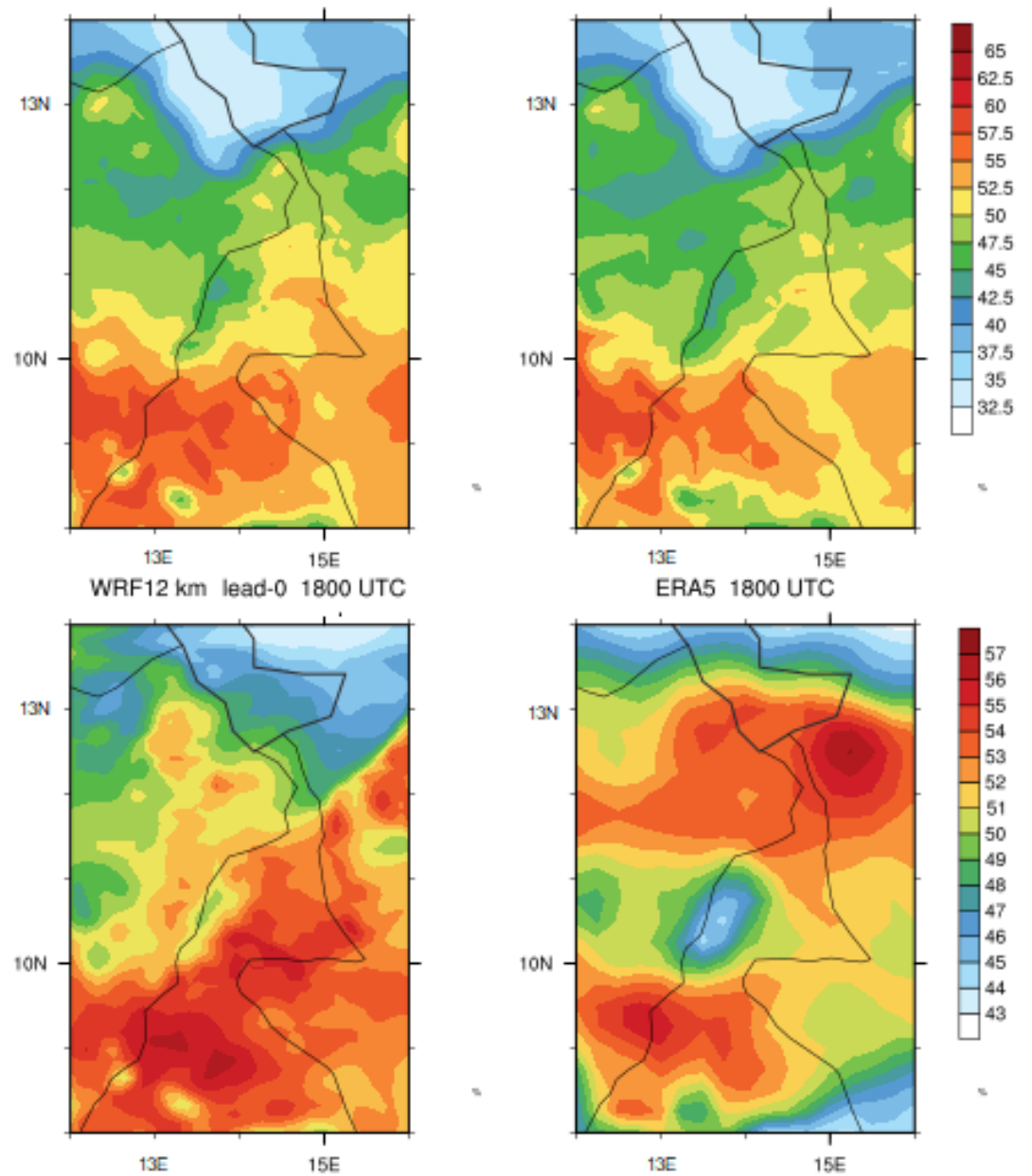

Figure 7

Same as Fig.4, but at 1800 UTC. 

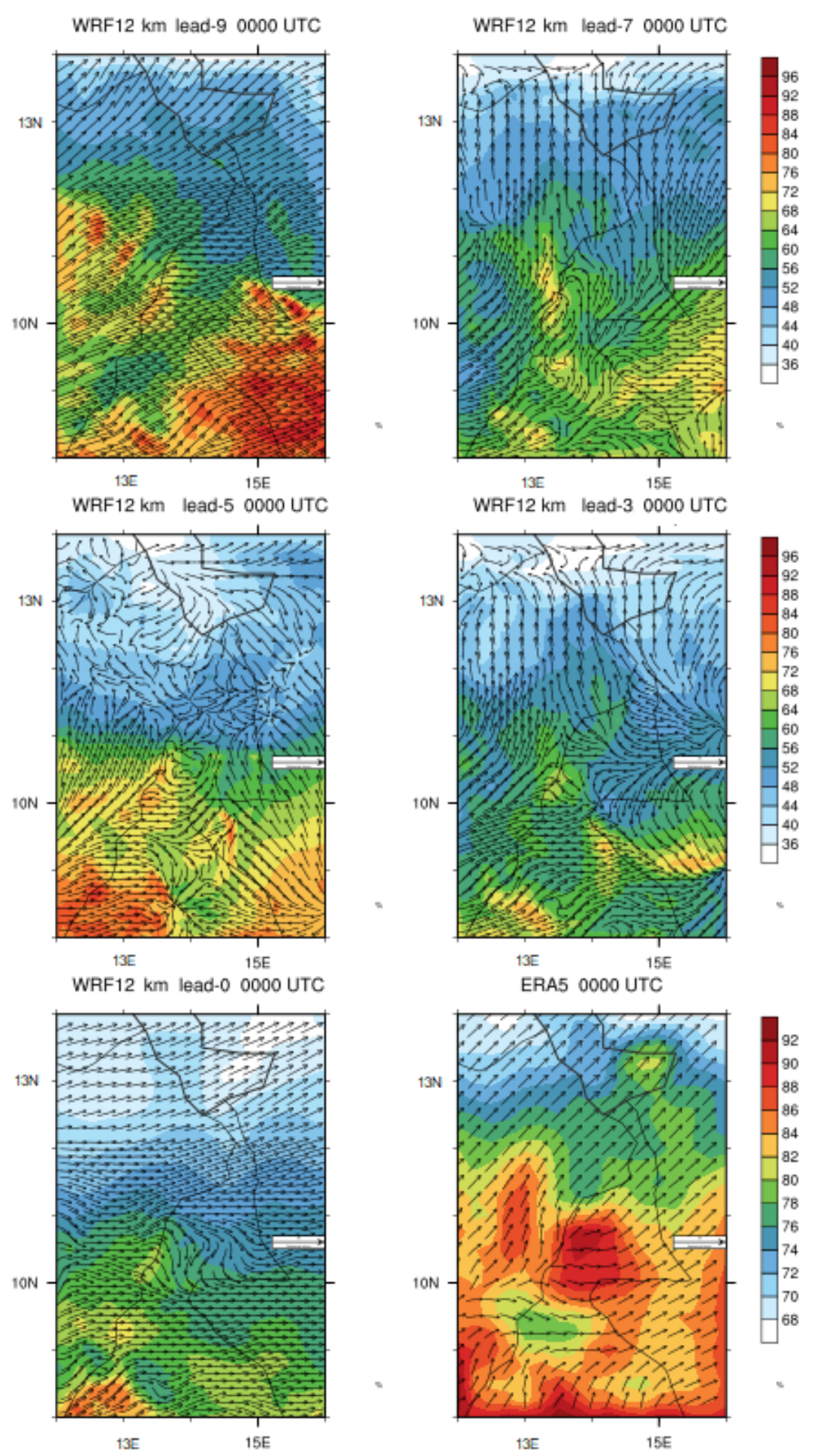

\section{Figure 8}

Comparison of WRF simulated data with ERA5 data wind vector $(\mathrm{m} / \mathrm{s})$ and relative humidity $(\%$ shaded) at the surface, at 0000 UTC for lead time 9, 7, 5, 3 and 0. 
WRF12 km lead-9 0600 UTC

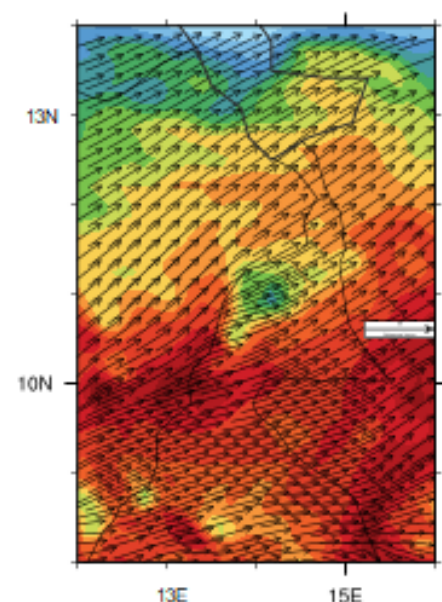

$13 E$

15E WRF12 km lead-5. 0600 UTC

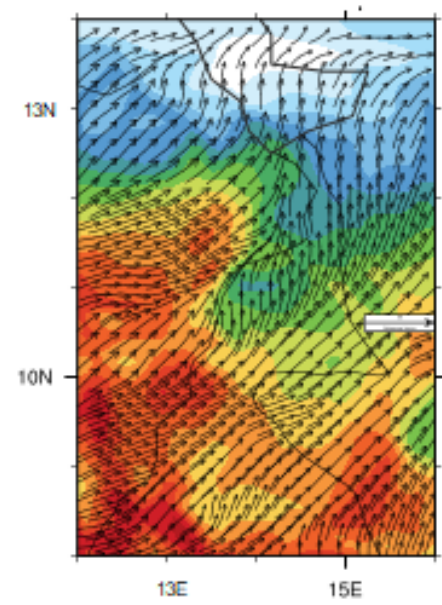

WRF12 km lead-0 0600 UTC

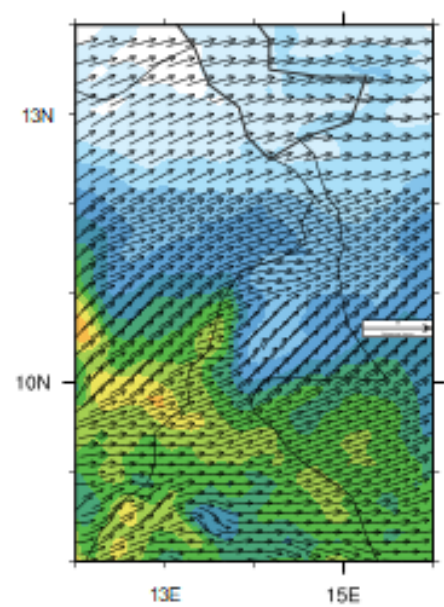

WRF12 km lead-7 0600 UTC
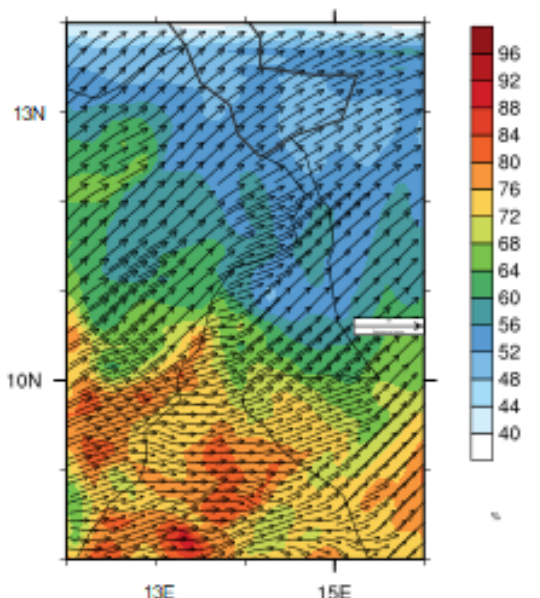

WRF12 km lead-3 0600 UTC
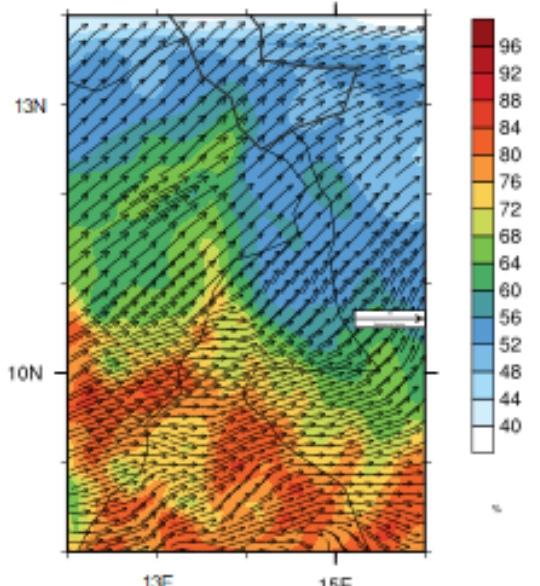

$3 E$

ERA5 0600 UTC
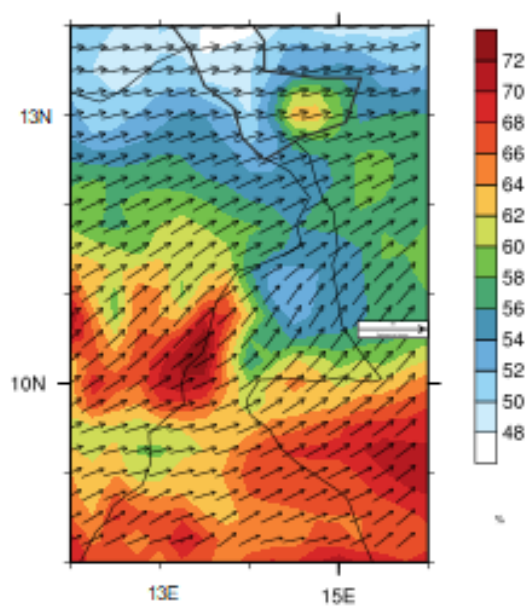

\section{Figure 9}

Same as Fig. 8, but at 0600 UTC. 

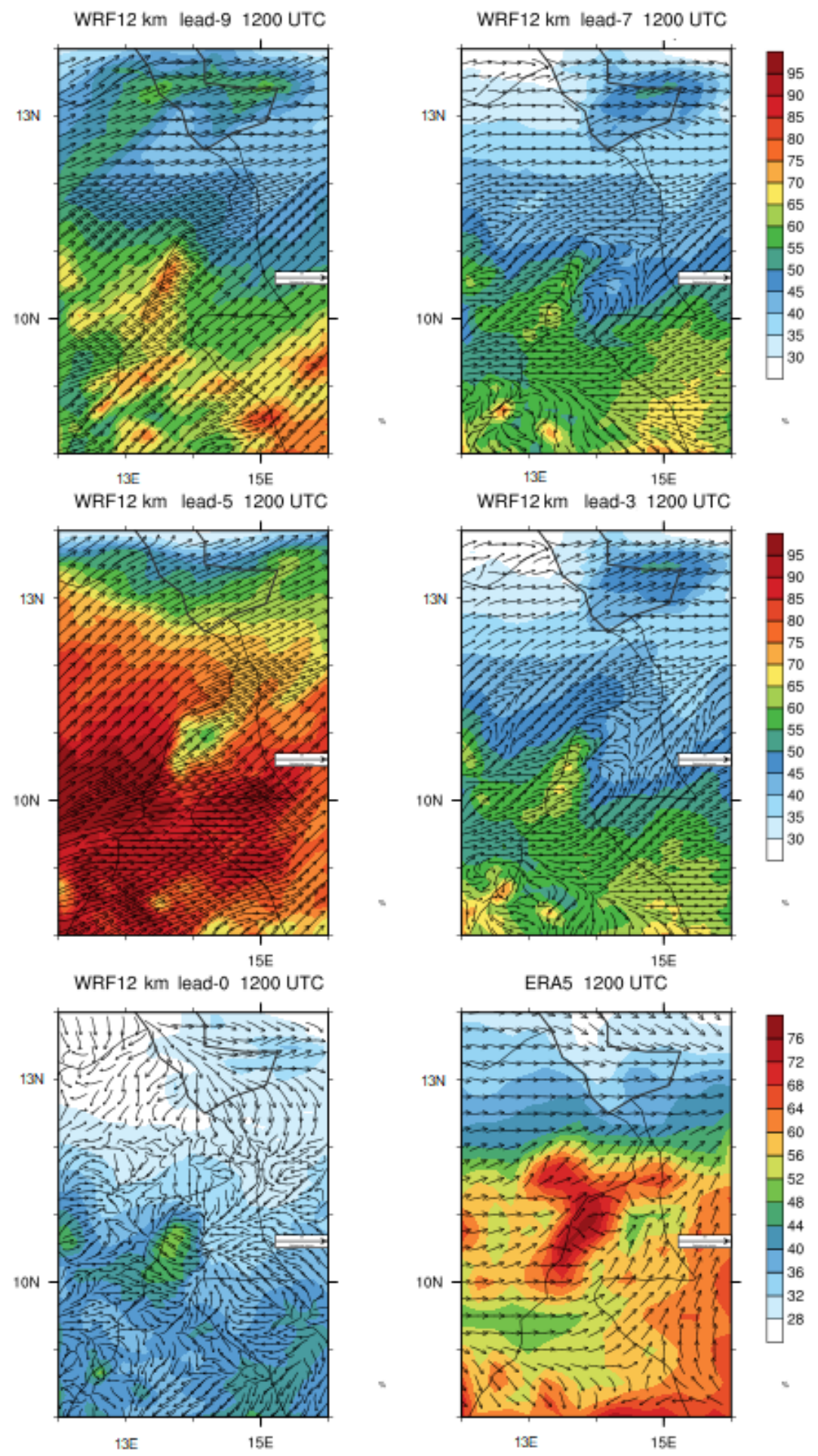

Figure 10

Same as Fig. 8, but at 1200 UTC.

Figure 11 
Same as Fig. 8, but at 1800 UTC.
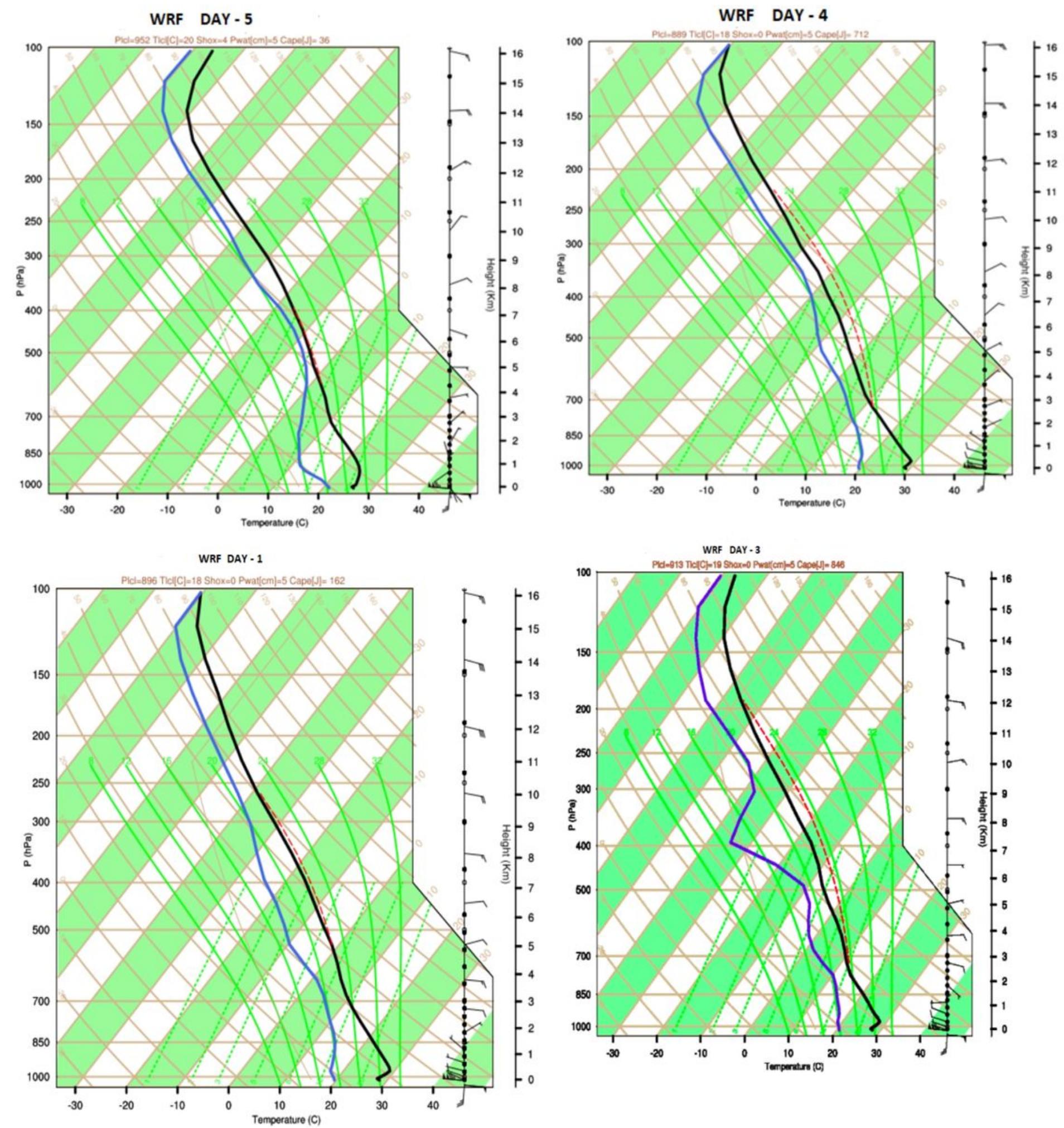

Figure 12 
Target day (23 July 2018), $\mathrm{PlCl}$ and $\mathrm{T} / \mathrm{c} /$ the pressure (hPa) and the temperature $\left({ }^{\circ} \mathrm{C}\right)$ at the lifting condensation level, Shox Showater index, Pwat the amount of precipitable water, Cape the convective available potential energy $(\mathrm{J})$ for the lead times day-5, day-4, day-3 and day- 1 .
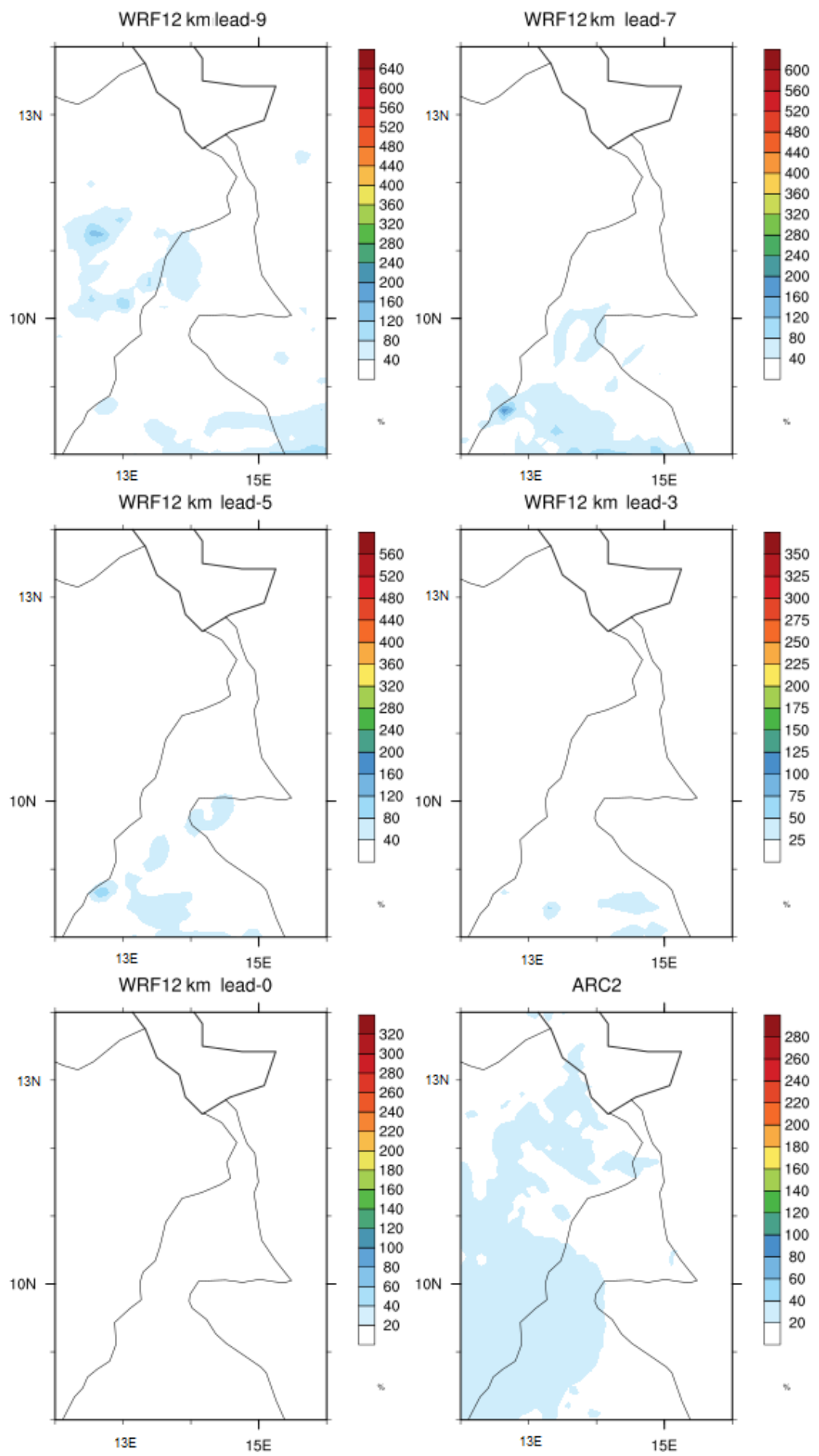

Figure 13

Accumulated rainfall (mm): WRF model simulated and ARC2; recorded for lead time 9, 7, 5, 3 and 0. 
Page 24/24 